\title{
Middle Miocene oxygen minimum zone expansion offshore West Africa: evidence for global cooling precursor events
}

\author{
S. Kender, British Geological Survey, Keyworth, Nottingham NG12 5GG, UK, corresponding \\ authoremail:sev.kender@bgs.ac.uk \\ V.L. Peck, British Antarctic Survey, High Cross, Madingley Road, Cambridge CB3 OET, UK \\ R.W. Jones, BP, Chertsey Road, Sunbury-on-Thames, Middlesex TW16 7LN, UK \\ M.A. Kaminski, Department of Earth Sciences, University College London, Gower Street, London \\ WC1E 6BT
}

\begin{abstract}
Citation: Kender, S., Peck, V.L., Jones, R.W., Kaminski, M.A. 2009. Middle Miocene oxygen minimum zone expansion offshore West Africa: Evidence for global cooling precursor events. Geology, 37, 699-702, doi: 10.1130/G30070A.1
\end{abstract}

\begin{abstract}
Three dissolution events have been identified in sediments from the Congo Fan at $\sim 16 \mathrm{Ma}, 15.5 \mathrm{Ma}$ and 14.3 Ma. Multi-proxy benthic foraminiferal and sedimentary records suggest an expanded oxygen minimum zone consistent with enhanced upwelling at these times. Marine carbonate records from adjacent North Africa indicate coincident episodes of increased continental weathering, suggesting that an intermittently stronger polar front strengthened West African offshore winds increasing surface water productivity, and enhanced North African weathering during these events. We propose that Columbia River Flood Basalt volcanism, estimated to have released $10^{6} \mathrm{Tg} \mathrm{CO}_{2}$ and $10^{6} \mathrm{Tg} \mathrm{\textrm {SO } _ { 2 }}$ between 16-15.6 Ma, may have influenced these climatic changes.
\end{abstract}

Keywords: Middle Miocene, Congo Fan, foraminifera, dissolution, Columbia River volcanism

\section{Introduction}

The Miocene Climatic Optimum (MCO), 17-14 Ma, represents a period of considerable climate variability that has proved difficult to understand for a number of reasons. Low mean-ocean $\delta^{18} \mathrm{O}$ values, representing the warmest global temperatures of the Neogene, coincided with abnormally high mean-ocean $\delta^{13} \mathrm{C}$ values (Zachos et al., 2001), initially considered to be the result of enhanced ocean productivity and burial of organically preferred ${ }^{12} \mathrm{C}$ in areas like Monterey, California, and other localities around the Pacific rim (Vincent and Berger, 1985). This 'Monterey Hypothesis' proposed global cooling as a mechanism to increase burial of organic carbon through zones of increased upwelling and productivity. However, the hypothesis did not explain increasing $\delta^{13} \mathrm{C}$ and global temperatures before $\sim 16 \mathrm{Ma}$. Furthermore the draw-down of atmospheric $\mathrm{pCO}_{2}$, predicted by the Monterey Hypothesis as the biological carbon pump accelerated, was not evident in reconstructions of atmospheric $\mathrm{pCO}_{2}$ through 17-14 Ma (Pagani et al., 1999) leading some to question the link between $\mathrm{CO}_{2}$ and Miocene climate (Shevenell et al., 2004; Pagani et al., 2005; Holbourn et al., 2007). However, high-resolution benthic isotope records from ODP Sites 1146 and 1237 in the Pacific recently revealed covariance between high $\delta^{18} \mathrm{O}$ and high $\delta^{13} \mathrm{C}$ in the order of obliquity (41 kyr) cycles (Holbourn et al., 2007), suggesting cooler episodes during Milankovichscale cycles may have enhanced ${ }^{12} \mathrm{C}$ burial through strengthened upwelling. Furthermore, recent stomatal frequency records from fossil leaves (Kürschner et al., 2008) and model simulations (You et al., 2009) indicate that atmospheric $\mathrm{pCO}_{2}$ may well have been significantly higher during the MCO (Fig. 2a) than previously thought, suggesting that carbon cycle perturbations did play a large part in Miocene climate change. 
Detailed analyses of sediments from beneath zones of upwelling are scarce, largely due to the generally non-calcareous nature of sediments beneath these eutrophic environments. Such regions however are critical to our understanding of the carbon cycle, as they document the history of one of the most important global carbon sinks. Here we report the first record of changes to the upwelling history of the Congo Fan, 22-14 Ma, from benthic foraminiferal assemblages and isotope records, allowing us to present a more detailed and complete analysis of the MCO before 14 Ma. Congo Fan sediments are almost entirely non-calcareous in the Oligocene and much of the Miocene as high surface water productivity and fluvial input/runoff likely encouraged extensive scavenging by benthic organisms as well as releasing $\mathrm{CO}_{2}$, acidifying bottom waters prohibiting the precipitation and preservation of calcium carbonate. The record of benthic foraminifera in this well is of particular interest as significant calcareous preservation was encountered throughout the Miocene, allowing benthic $\delta^{18} \mathrm{O}$ and $\delta^{13} \mathrm{C}$ to be obtained from Cibicidoides spp., and the development of a relatively robust age model (Kender et al., 2009).

\section{Materials}

The study well was drilled by BP in the distal section of the Congo Fan (Block 31, 200 km offshore Angola) at $2000 \mathrm{~m}$ water depth. The Oligocene section consists of predominantly noncalcareous silts and clays (Kender et al., 2008). Lower-Middle Miocene sediments consist of fine grained silt and clay distal turbidites with sand content $<3 \%$ (Kender et al., 2009). Drill cuttings were collected at $10 \mathrm{~m}$ intervals from 2750-3400 m (below rotary table). Although no large-scale caving (younger material from higher in the hole becoming amalgamated with older material) has been reported in this well (Kender et al., 2009), interpretations from this study are based on largescale trends and not individual data. From each $\sim 100 \mathrm{~g}$ sample, all foraminifera $>125 \mu \mathrm{m}$ were identified and counted (smaller fractions were not included due to the bias associated with low fossilisation potential of smaller delicate specimens). Fisher's Alpha diversity was calculated using software of Hammer et al. (2001). Changes in benthic oxygen levels were estimated using a modern calcareous benthic foraminiferal assemblage analogue technique (Corliss, 1991; Kaiho, 1994), species in this study being assigned to groups based on their morphological similarity to the modern forms where the species is extinct. The Kaiho (1994) benthic foraminiferal oxygen index (BFOI) was used to estimated the level of dissolved oxygen in the sediment at low values based on the relative proportions of three groups of calcareous benthic foraminifera associated with oxic, suboxic and dysoxic conditions (see Kaiho, 1994 for detailed methodology). Samples analysed contained between 40-600 specimens. Stable isotopes were obtained from Cibicidoides spp. (C. mundulus and C. pachyderma were preferentially used where available), 2-5 specimens $>250 \mu \mathrm{m}$ taken where possible. Crushed specimens were then immersed in 3\% hydrogen peroxide for $30 \mathrm{~min}$, ultrasonicated in methanol for $15 \mathrm{~s}$, excess residue and liquid removed, and dried at $45^{\circ} \mathrm{C}$. Stable isotope analysis was conducted using a ThermoFinnigan MAT 252 and coupled carbonate preparation device at Cardiff University, with an external reproducibility of $\leq 0.08 \%$ for $\delta^{18} \mathrm{O}$ and reported on the VPDB scale. Values of $\delta^{18} \mathrm{O}$ recorded from Cibicidoides spp. have been adjusted by $+0.64 \%$ to align them with equilibrium calcification at given temperature and $\delta^{18} \mathrm{O}_{\text {sw }}$ (Shackleton and Opdyke, 1973). Bulk rock total organic carbon (TOC) determined with an Elementar VarioMax $\mathrm{C}, \mathrm{N}$ analyser via high temperature combustion at BGS. Age model follows that of Kender et al. (2009) based on 9 foraminiferal, nannofossil and isotope markers. Data from this well is plotted against Lourens et al. (2004) timescale.

\section{Results}

Benthic foraminiferal assemblages show significant variability in absolute abundance, diversity, calcareous content and species composition from 17-14 Ma (Fig.1). The relative abundance of calcareous specimens increases steadily up section, and from $\sim 16 \mathrm{Ma}$ oscillates abruptly from dominating the assemblage to forming a minor component. TOC varies from between $\sim 2-4 \mathrm{wt} . \%$, with maximum values recorded 16-14 Ma. Benthic $\delta^{18} \mathrm{O}$ and $\delta^{13} \mathrm{C}$ values show trends similar to the 
global composite (Zachos et al., 2001) up to 16 Ma. Benthic foraminifera oxygen index (BFOI) averages $\sim 100$ up to $16 \mathrm{Ma}$, and then fluctuates between 30 and -40 . Low oxygen zones are shaded on Fig. 1 and characterised by BFOI $<50$, indicating a maximum dissolved oxygen concentration of $<3 \mathrm{ml} / 1$ (Kaiho, 1994). The dominating low oxygen species between 16-14 Ma in this study include Bulimina elongata, Brizalina alazanensis, Bulimina marginata and Valvulineria pseudotumeyensis. Dominant oxic indicators are Oridorsalis umbonatus and Cibicidoides crebbsi. The BFOI index uses calcareous foraminifera only, and therefore is not calculated in zones of low calcareous abundance, as occurring between 19 and $22 \mathrm{Ma}$.

\section{Discussion}

\section{West African upwelling}

Low benthic foraminiferal diversity and BFOI suggest benthic oxygen concentrations at this location fell below $3 \mathrm{ml} / 1$ between $\sim 15.7-14 \mathrm{Ma}$ (Fig. 1). This proxy has considerable uncertainties in predicting absolute values (Jorissen et al., 2007), but we can be confident that the local oxygen minimum zone (OMZ) was proximal to this site within this time interval. A Miocene paleodepth of $\sim 1000 \mathrm{~m}$ for this site (Kender et al., 2009) suggests a significant expansion of the OMZ, as comparably low dissolved oxygen values today are reached at $<1000 \mathrm{~m}$ in this location (eWOCE data). Less direct evidence for an expanded OMZ includes elevated levels of TOC and large variations in absolute foraminiferal abundance (Fig. 1), properties associated with OMZs today (e.g. Levin, 2003; Schumacher et al., 2007). Agglutinated species with high abundance over this interval include Glomospira spp., a genus associated with zones of reduced oxygen (Kaminski and Gradstein, 2005). Schumacher et al. (2007) reported large fluctuations in species abundance and composition within different levels of the OMZ off the Pakistan margin with consistently low diversity and faunal domination by known low-oxygen tolerating species (Corliss, 1991; Kaiho, 1994). Additionally, Dissolution Events 1 to 3 (DE1-3, Fig. 2) also suggest periods of increased upwelling and surface water productivity, as increased benthic scavenging is known to cause more acidic bottom water (Diester-Haass, 1988), and upwelling waters can be more acidic (e.g. Feely et al., 2008). It is possible that this site became periodically shallower during sea level falls at 15 and $16 \mathrm{Ma}$ (Haq et al., 1987), but this is unlikely to have caused the observed low oxygen faunas as the likely sea level change $(<100 \mathrm{~m})$ was not significant, and the rise in sea level at $15.5 \mathrm{Ma}$ (Haq et al., 1987) does not correspond with high-oxygen faunas. Expansion of the OMZ appears to result from upwelling of cold, nutrient-rich bottom waters (as opposed to increased terrestrial nutrient runoff alone) as indicated by the positive shift in $\delta^{18} \mathrm{O}$ at $\sim 16 \mathrm{Ma}$, which is a departure from the global composite trend and therefore unlikely to reflect global ice growth.

High surface water productivity along the West African margin today is associated with strong offshore winds, resulting from the Intertropical Convergence Zone (ITCZ) latitudinal thermal gradient (Levin, 2003). It seems likely that stronger offshore winds and increased upwelling, indicated by the positive shift in benthic $\delta^{18} \mathrm{O}$, were responsible for the Middle Miocene OMZ expansion reported here. Increased upwelling has been recorded from eastern Walvis Ridge sediments during glacial intervals over the last $420 \mathrm{ky}$ (Ufkes et al., 2000), lending evidence for Antarctic cooling as a mechanism for the Middle Miocene OMZ expansion. It seems likely that Congo Fan OMZ expansion was initiated at $\sim 16 \mathrm{Ma}$, as evidenced by DE1 and increased $\delta^{18} \mathrm{O}$ in our records, with local oxygen concentrations of $<3 \mathrm{ml} / 1$ reaching $\sim 1 \mathrm{~km}$ depth by $\sim 15.7 \mathrm{Ma}$ (inception of low oxygen fauna). The entire West African margin likely experienced episodic increased upwelling and surface water productivity over the Middle Miocene, as zones of dissolution associated with increased upwelling are also recorded in low resolution records from DSDP Sites 362-363 (Melguen, 1978; Diester-Haass, 1988) on the eastern Walvis Ridge (Fig. 1b) starting from around 16-14 Ma. Early-Middle Miocene sedimentary records from the Maltese North African margin support a periodic northward migration of the ITCZ (from an enhanced latitudinal temperature gradient) between $\sim 16.3-15.2 \mathrm{Ma}$, from a record of decreased carbonate 
content in marine sediments over this interval (Fig. 2) suggesting greater terrestrial input from increased rainfall in north Africa (John et al., 2003). Our record of calcareous foram shell abundance largely mirrors this trend, with Congo Fan dissolution cycles DE1-3 correlating with enhanced North African weathering (Fig. 2).

\section{Implications for the Miocene Climatic Optimum}

Both our record from the Congo Fan and that from Malta (John et al., 2003) indicate that Middle Miocene Africa experienced the effects of a northward migrating polar front (John et al., 2003), with three episodes of intensification, DE1-3. The implication is that significant cooling episodes, lasting in the region of 100-300 kyrs, occurred prior to the major global cooling event at $14 \mathrm{Ma}$. The period 16-14 Ma has traditionally been considered a climatically optimal time in Earth's history due to generally warm global temperatures $\left(\delta^{18} \mathrm{O}\right.$ and $\mathrm{Mg} / \mathrm{Ca}$ records). However, evidence for periodic global cooling at this time comes from documented changes in ocean circulation from benthic $\delta^{13} \mathrm{C}$ records (Wright et al., 1992), and the significantly increased influence of Southern Component Water at ODP Site 1123, offshore New Zealand, from 15.6 Ma, suggesting invigorated deep-water formation associated with East Antarctic Ice Sheet (EAIS) expansion (Hall et al., 2003). An ultrahigh resolution record of planktonic $\mathrm{Mg} / \mathrm{Ca}$ ratios at ODP Site 1170 in the Southern Ocean shows increased variability in surface ocean temperature between 16-15.2 Ma, and an overall fall from 20 to $13^{\circ} \mathrm{C}$ (Shevenell et al., 2004). Our results from the Congo Fan also support evidence that increased deep-water ventilation caused a global turnover in benthic foraminiferal species at this time (Thomas, 2007).

Understanding what caused these climatic perturbations during the Middle Miocene has proven difficult. Our record of increased upwelling on the Congo Fan lends further evidence for globally increased organic carbon burial over the MCO, increasing mean-ocean $\delta^{13} \mathrm{C}$ (Vincent and Berger, 1985). The closure of the Tethys Ocean at $\sim 18 \mathrm{Ma}$, and reopening briefly at $\sim 16-15 \mathrm{Ma}$ (Flower and Kennett, 1994), and the subsidence of the Iceland Plateau from 18-14 Ma (Schnitker, 1980), have both been suggested to have increased poleward heat and moisture transport, causing increased precipitation and aiding ice growth. These mechanisms alone, however, cannot account for high benthic $\delta^{18} \mathrm{O}$ and apparently high atmospheric $\mathrm{pCO}_{2}$ (Kürschner et al., 2008) between $\sim 16-15 \mathrm{Ma}$.

\section{Influence of Columbia River Volcanism}

The Columbia River Basalt Group (CRBG), Earth's youngest continental flood basalt province, saw 90\% of its eruptions take place between 16.1-15 Ma (Hooper et al., 2002, Fig. 2). Assuming a conservative volatile content of $0.5 \mathrm{wt} . \% \mathrm{CO}_{2}$ of the released magma, and an $80 \%$ efficient degassing, $11.2 \mathrm{Tg} \mathrm{CO}_{2}$ would have been released for every $1 \mathrm{~km}^{3}$ of basaltic lava (Self et al., 2006). This gives an estimated release of $672,000 \mathrm{Tg} \mathrm{CO}_{2}$, or $\sim 80 \mathrm{ppmv}$ of $\mathrm{pCO}_{2}$ equivalent, over $400 \mathrm{kyr}$ between 16-15.6 Ma (DE1-2), assuming an average CRBG lava release rate of 150,000 $\mathrm{km}^{3} /$ my (Hooper et al., 2002, Fig. 2). The $\mathrm{CO}_{2}$ would likely have been released over multiple eruptive episodes (Roza eruption estimated as $\sim 10$ yrs duration, see Thordarson and Self, 1999), with biological feedback mechanisms reducing $\mathrm{pCO}_{2}$ over thousands of years $(\mathrm{PETM} \mathrm{CO} 2$ was sequestered within $\sim 60 \mathrm{kyr}$, see Bains et al., 2000). Lang (2002) estimate volatile content for CRBG magmas of $2 \mathrm{wt} . \%$, which would increase these $\mathrm{CO}_{2}$-emission estimates four-fold. Erupted carbon would have been enriched in ${ }^{12} \mathrm{C}$ relative to the global average. A negative $\delta^{13} \mathrm{C}$ anomaly at $\sim 16.2$ $\mathrm{Ma}$ in the composite record (Zachos et al., 2001) immediately prior to the positive $\delta^{13} \mathrm{C}$ excursion may reflect the first influx of $\mathrm{CRBG} \mathrm{CO}_{2}$.

In addition to $\mathrm{CO}_{2}$, Self et al. (2006) estimate $7.3 \mathrm{Tg}$ of $\mathrm{SO}_{2}$ were released per $1 \mathrm{~km}^{3}$ of lava for the Roza eruption in the CRBG, giving an average of $\sim 1,100,000 \mathrm{Tg} \mathrm{\textrm {SO } _ { 2 }}$ released between 16-15.6 Ma using the assumptions above. This was a significant emission, as the average amount of sulphur in the atmosphere today is $<1 \mathrm{Tg}$ (Self et al., 2006). The detailed timing of CRBG eruptive events is 
unknown. Also, the climatic effects of such massive sulphur injection, and the balance between short term cooling from volcanic winters and $\mathrm{CO}_{2}$-induced warming, are yet to be fully understood and modelled (Self et al., 2005). However resultant volcanic aerosol clouds likely produced significant global cooling in the immediate aftermath of eruptions lasting in the order of decades per eruptive episode. A $\sim 0.4 \%$ increase in benthic $\delta^{18} \mathrm{O}$ (Zachos et al., 2001) associated with the first CRBG eruption and negative $\delta^{13} \mathrm{C}$ anomaly suggests an abrupt global cooling of up to $2{ }^{\circ} \mathrm{C}$ as the positive benthic $\delta^{13} \mathrm{C}$ excursion develops. We consider that volcanic winters may have cooled the climate sufficiently to strengthen offshore winds and initiate the widespread upwelling and enhanced productivity documented in the Pacific (e.g. Flower and Kennett, 1994) and off West Africa (this study). Also, increased weathering of North Africa likely fertilized the ocean (e.g. nitrates, phosphates) and further contributed to carbon burial. Such a climate regime may have been maintained by further eruptive episodes until carbon burial had drawn-down sufficient atmospheric $\mathrm{CO}_{2}$, perhaps around DE-3, to sustain cooler temperatures and promote expansion of the EAIS. The closure of Tethys and subsidence of Iceland Plateau may also have promoted cooling at this time, by allowing greater heat and moisture transport to high latitudes.

\section{Conclusions}

We have presented evidence consistent with an expanded OMZ at mid-lower bathyal depths over the Congo Fan from 15.7-14 Ma, with three dissolution events (DE1-3) at $16 \mathrm{Ma}, 15.5 \mathrm{Ma}$ and 14.3 Ma marking likely periodic maxima in upwelling. Correlation of these multi-proxy records with North African continental weathering records reveals coincidence of increased North African weathering and West African OMZ expansion during these events. These represent periods of episodic polar cooling prior to $14 \mathrm{Ma}$ that likely led to an enhanced latitudinal thermal gradient, increasing both continental weathering in North Africa through a northward migrating ITCZ, and the extent of the West African OMZ through enhanced offshore winds and surface water productivity. Recent indications that atmospheric $\mathrm{pCO}_{2}$ may have been significantly increased over this interval appears to point to the coincident release of Columbia River flood basalts as a possible cause of cooling and climatic perturbation during DE1 and DE2, although mechanisms for this remain unclear.

\section{Acknowledgements}

This research was partly funded by BP, who also provided all samples. We would like to thank Ian Hall (Cardiff University) for isotope analysis, Chris Vane (BGS) for TOC analysis, and J. Reis and an anonymous reviewer for insightful comments. Published with permission of the Executive Director of the British Geological Survey (NERC).

\section{References}

Bains, S., Norris, R.D., Corfield, R.M., and Faul, K.L., 2000, Termination of global warmth at the Palaeocene/Eocene boundary through productivity feedback: Nature, v. 407, p. 171-174, doi: 10.1038/35025035.

Corliss, B.H., 1991, Morphology and microhabitat preferences of benthic foraminifera from the northwest Atlantic Ocean: Marine Micropaleontology, v. 17, p. 195-236, doi:10.1016/03778398(91)90014-W.

Diester-Haass, L., 1988, Sea level changes, carbonate dissolution and history of the Benguela Current in the Oligocene-Miocene off Southwest Africa (DSDP Site 362, Leg 40): Marine Geology, v. 79, p. 213-242, doi:10.1016/0025-3227(88)90040-0. 
Feely, R.A., Sabine, C.L., Hernandez-Ayon, J.M., Ianson, D., and Hales, B., 2008, Evidence for Upwelling of Corrosive "Acidified" Water onto the Continental Shelf: Science, v. 320, p. 14901492, doi:10.1126/science.1155676.

Flower, B.J., and Kennett, J.P., 1994, The Middle Miocene climatic transition: East Antarctic ice sheet development, deep sea circulation, and global carbon cycling: Palaeogeography, Palaeoclimatology, Palaeoecology, v. 108, p. 537-555, doi:10.1016/0031-0182(94)90251-8.

Hall, I. R., McCave, N., Zahn, R., Carter, L., Knutz, P.C., and Weedon, G.P., 2003, Paleocurrent reconstruction of the deep Pacific inflow during the middle Miocene: Reflections of East Antarctic Ice Sheet growth: Paleoceanography, v. 18, doi:10.1029/2002PA000817.

Hammer, Ø., Harper, D.A.T. and Ryan, P.D., 2001, PAST: Palaeontological Statistics software package for education and data analysis: Palaeontologia Electronica, v. 4, p. 9.

Haq, B. U., Hardenbol, J., and Vail, P. R., 1987, Chronology of fluctuating sea level since the Triassic. Science, v. 235, p. 1136-1167, doi: 10.1126/science.235.4793.1156

Herold, N., Seton, M., Müller, R. D., You, Y., and Huber, M., 2008, Middle Miocene tectonic boundary conditions for use in climate models: Geochemistry Geophysics Geosystems, v. 9, doi:10.1029/2008GC002046.

Holbourn, A., Kuhnt, W., Schulz, M., Flores, J., and Andersen, N., 2007, Orbitally-paced climate evolution during the middle Miocene "Monterey" carbon-isotope excursion: Earth and Planetary Science Letters, v. 261, p. 534-550, doi: 10.1016/j.eps1.2007.07.026.

Hooper, P.R., Binger, G.B., and Lees, K.R., 2002, Ages of the Steens and Columbia River flood basalts and their relationship to extension-related calc-alkalic volcanism in eastern Oregon: GSA Bulletin, v. 114, p. 43-50, doi: 2002014.

John, C.M., Mutti, M., and Adatte, T., 2003, Mixed carbonate-siliciclastic record on the North African margin (Malta) - coupling of weathering processes and mid Miocene climate: GSA Bulletin, v. 115, p. 217-229, doi: 2003032.

Jorissen, F.J., Fontanier, C., and Thomas, E., 2007, Paleoceanographical proxies based on deep-sea benthic foraminiferal assemblage characteristics, in Hillaire-Marcel, C., and De Vernal, A., eds., Proxies in Late Cenozoic Paleoceanography, Elsevier Publishers, p. 277-340.

Kaiho, K., 1994, Benthic foraminiferal dissolved-oxygen index and dissolved-oxygen levels in the modern ocean: Geology, v. 22, p. 719-722, doi: 10.1130/00917613(1994)022<0719:BFDOIA $>2.3 . C O ; 2$.

Kaminski, M.A., and Gradstein, F.M., 2005, Atlas of Paleogene cosmopolitan deep-water agglutinated foraminifera: Grzybowski Foundation Special Publication, v. 10, 547 pp.

Kender, S., Kaminski, M.A., and Jones, B.W., 2009, Early to Middle Miocene Foraminifera from the deep-sea Congo Fan, Offshore Angola: Micropaleontology, v. 54, p. 477-568.

Kender, S., Kaminski, M.A., and Jones, B.W., 2008, Oligocene deep-water agglutinated foraminifera from the Congo Fan, offshore Angola: palaeoenvironments and assemblage distributions, in Kaminski, M.A. and Coccioni, R., eds., Proceedings of the Seventh International Workshop on Agglutinated Foraminifera: Grzybowski Foundation Special Publication, v. 13, p. 107-156. 
Kürschner, W.M., Kvacek, Z., and Dilcher, D.L., 2008, The impact of Miocene atmospheric carbon dioxide fluctuations on climate and the evolution of terrestrial ecosystems: Proceedings of the National Academy of Sciences of the USA, v. 105, p. 449-453, doi: 10.1073/pnas.0708588105.

Lange, R.A., 2002, Constraints on the pre-eruption volatile contents in the Columbia River flood basalts: Geology, v. 30, p. 179-182, doi: 10.1130/0091-7613(2002)030<0179:COTPVC>2.0.CO;2.

Levin, L.A., 2003, Oxygen minimum zone benthos: adaptation and community response to hypoxia: Oceanography and Marine Biology: an Annual Review, v. 41, p. 1-45.

Lourens, L.J., Hilgen, F.J., Laskar, J., Shackleton, N.J., and Wilson, D., 2004, The Neogene Period, in Gradstein, F.M. and others, eds., A geologic time scale 2004: Cambridge University Press, Cambridge, p. 409-440.

Melguen, M., 1978, Facies evolution, carbonate dissolution cycles in sediments from the eastern south Atlantic (DSDP Leg 40) since the early Cretaceous, in Bolli, H.M., Ryan, W.B.F., and others, eds., Initial Reports of the Deep Sea Drilling Project, v. 40, U.S. Government printing office, Washington D.C., p. 981-1024.

Pagani, M., Authur, M.A., and Freeman, K.H., 1999, Miocene evolution of atmospheric carbon dioxide: Paleoceanography, v. 14, p. 273-292.

Pagani, M., Zachos, J., Freeman, K. H., Bohaty, S., and Tipple, B., 2005, Marked change in atmospheric carbon dioxide concentrations during the Oligocene: Science, v. 309, p. 600-603, doi: 10.1126/science.1110063.

Schnitker, D., 1980, North Atlantic oceanography as possible cause of Antarctic glaciation and eutrophication: Nature, v. 284, p. 615-616, doi:10.1038/284615a0

Schumacher, S., Jorissen, F.J., Dissard, D., Larkin, K.E., and Gooday, A.J., 2007, Live (Rose Bengal stained) and dead benthic foraminifera from the oxygen minimum zone of the Pakistan continental margin (Arabian Sea): Marine Micropaleontology, v. 62, p. 45-73, doi:10.1016/j.marmicro.2006.07.004.

Self, S., Thordarson, T., and Widdowson, M., 2005, Gas fluxes from flood basalt eruptions: Elements, v. 1, p. 283-287.

Self, S., Widdowson, M., Thordarson, T., and Jay, A.E., 2006, Volatile fluxes during flood basalt eruptions and potential effects on the global environment: a Deccan perspective: Earth and Planetary Science Letters, v. 248, p. 517-531, doi: 10.1016/j.eps1.2006.05.041.

Shackleton, N. J., and N. J. Opdyke, 1973, Oxygen isotope and palaeomagnetic stratigraphy of equatorial Pacific core V28-238: Oxygen isotope temperatures and ice volumes on a $10^{5}$ year and $10^{6}$ year scale: Quaternary Research, v. 3, p. 39-55, doi:10.1016/0033-5894(73)90052-5.

Shevenell, A.E., Kennett, J.P., and Lea, D.W., 2004, Middle Miocene Southern Ocean Cooling and Antarctic Cryosphere expansion: Science, v. 305, p. 1766-1770, doi: 10.1126/science.1100061

Thomas, E., 2007, Cenozoic mass extinctions in the deep sea: what perturbs the largest habitat on Earth?: The Geological Society of America Special Paper 424, p. 1-23, doi: 10.1130/2007.2424(01). 
Thordarson, T., and Self, S., 1996, Sulfur, chlorine and fluorine degassing and atmospheric loading by the Roza eruption, Columbia River Basalt Group, Washington, USA: Journal of Volcanology and Geothermal Research, v. 74, p. 49-73, doi:10.1016/S0377-0273(96)00054-6.

Ufkes, E., Jansen, J.H.F., and Schneider, R.R., 2000, Anomalous occurrences of Neogloboquadrina pachyderma (left) in a 420-ky upwelling record from Walvis Ridge (SE Atlantic): Marine Micropaleontology, v. 40, p. 23-42, doi:10.1016/S0377-8398(00)00030-X.

Vincent, E., and Berger, W.H., 1985, Carbon dioxide and polar cooling in the Miocene: the Monterey hypothesis, in Sundquist, E.T., and Broecker, W.S., eds., The Carbon Cycle and Atmospheric CO2: Natural Variations Archean to Present, Geophysical Monograph 32, p. 455-468.

Wright, J.D., Miller, K.G., and Fairbanks, R.G., 1992, Early and middle Miocene stable isotopes: implications for deepwater circulation and climate: Paleoceanography, v. 7, p. 357-389.

You, Y., Huber, M., Müller, R.D., Poulsen, C.J. and Ribbe, J., 2009, Simulation of the Middle Miocene Climate Optimum: Geophysical Research Letters, v. 36, L04702, doi:10.1029/2008GL036571.

Zachos, J., Pagani, M., Sloan, L., Thomas, E., and Billups, K., 2001, Trends, rhythms, and aberrations in global climate 65 Ma to present: Science, v. 292, p. 686-693, doi: 10.1126/science.1059412.

Figure 1. A, B: Benthic $\delta^{18} \mathrm{O}$ and $\delta^{13} \mathrm{C}$ raw data with 3-point running mean. C: Percentage of calcareous foraminifera to total benthic fauna (agglutinated + calcareous). D: Fisher's diversity index. E: BFOI (Kaiho, 1994). Areas of shading mark BFOI $<50(<3 \mathrm{ml} / \mathrm{l})$. F: Log faunal density (specimens per gram of dry sediment). G: Total organic carbon raw data with 3-point running mean. $\mathrm{H}$ : Paleogeographic reconstruction of African at $15 \mathrm{Ma}$ (Herold et al., 2008), with location of sites referred to in the text (BP well, this study; Malta section, John et al., 2003; DSDP 362-363, Melguen, 1978; Diester-Haass, 1988), and modern day ITCZ and OMZ.

Figure 2. A: Global atmospheric $\mathrm{pCO}_{2}$ from fossil leaf stomata frequency (Kürschner et al., 2008). B, C: Global benthic $\delta^{18} \mathrm{O}$ and $\delta^{13} \mathrm{C}$ data (Zachos et al., 2001). D: Benthic $\delta^{13} \mathrm{C}$ raw data with 3point running mean (this study). E: Percentage of calcareous foraminifera to total benthic fauna (this study). F: Total organic carbon raw data with 3-point running mean (this study). G: Percentage bulk carbonate from Maltese marine section (John et al., 2003). H: Dashed lines mark dissolution events DE1-3 (this study), where calcareous specimens account for $<50 \%$ of fauna. I: Columbia River Flood Basalt eruption rate (Hooper et al., 2002) for a. Columbia Plateau, b. Malheur Gorge and Steens Basalt. 


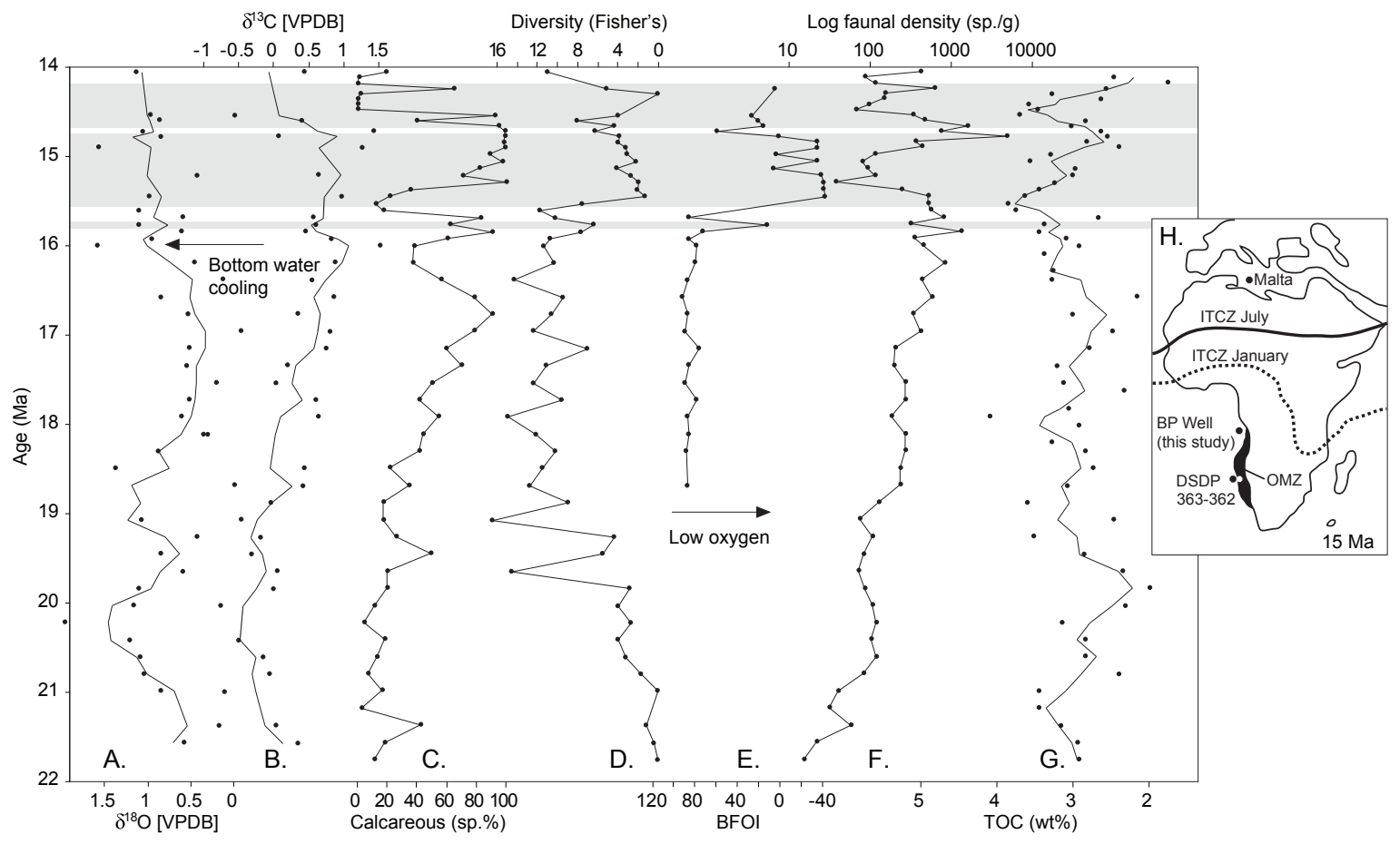

Figure 1.

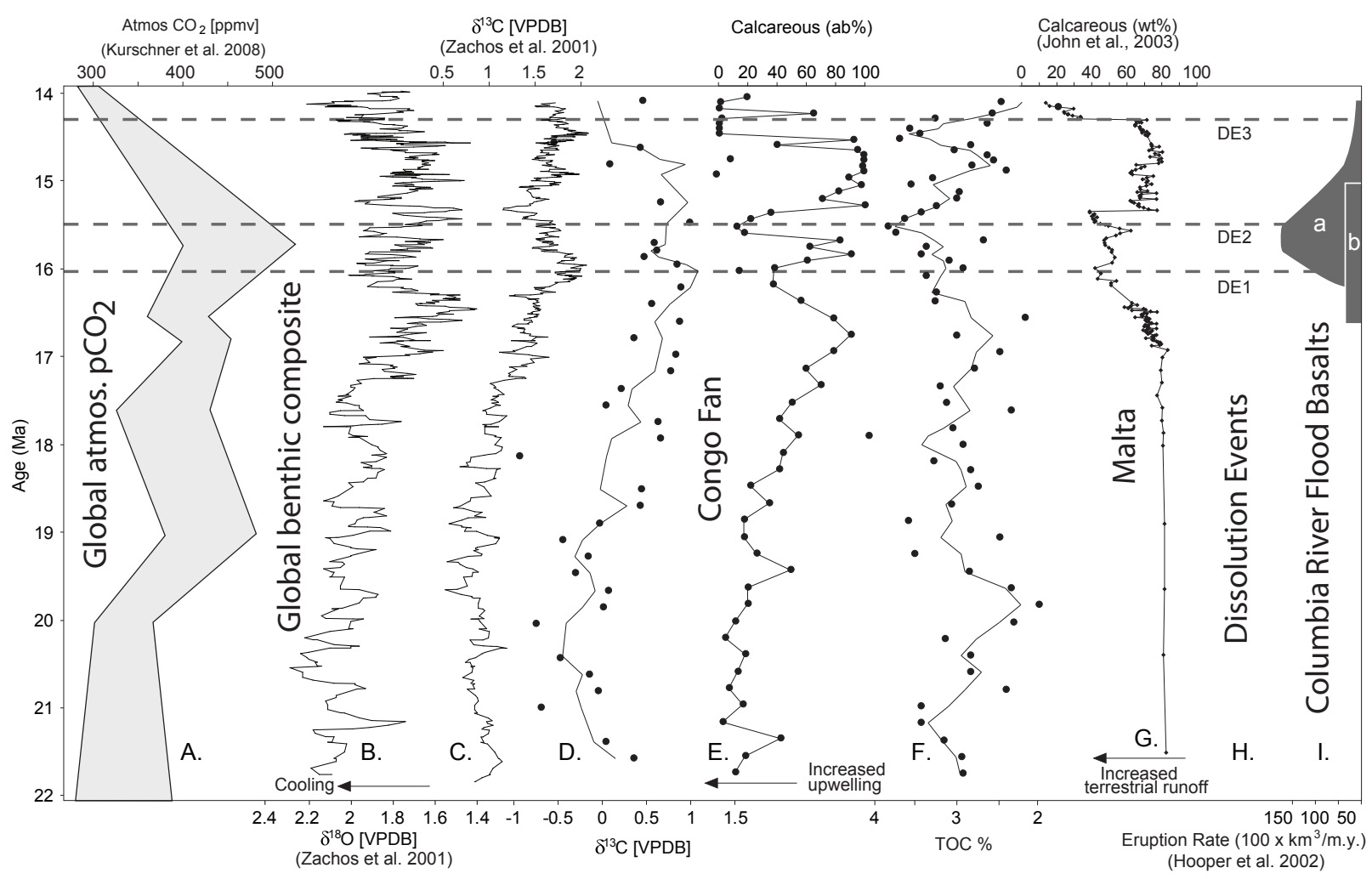

Figure 2. 